\title{
ONLINE VIDEO GAME: THE INNOVATION OF DENTAL HEALTH EDUCATION TOOLS FOR CHILDREN DURING COVID-19 PANDEMIC
}

\author{
Yufitri Mayasari* \\ Department of Dental Public Health, Faculty of Dentistry \\ Universitas Prof. Dr. Moestopo (Beragama) \\ Belanita \\ Department of Prosthodontia. Faculty of Dentistry \\ Universitas Prof. Dr. Moestopo (Beragama) \\ Elin Hertiana \\ Universitas Prof. Dr. Moestopo (Beragama) \\ *Correspondence: yufitrimayasari@dsn.moestopo.ac.id
}

$\begin{array}{ll}\text { ARTICLE INFO } & \text { ABSTRACT } \\ \text { Article History: } & \text { COVID-19 has presents unprecedent challenge in many aspects of } \\ \text { received: } 09 / 09 / 2020 & \text { dentistry include oral health promotion. Oral health promotion is } \\ \text { revised: } 12 / 11 / 2020 & \text { recognized an essential component to prevent the oral disease } \\ \text { accepted: } 13 / 01 / 2021 & \begin{array}{l}\text { during pandemic. As we know, dental caries is the most common } \\ \text { dental and oral health problem suffered by children due to } \\ \text { behaviour of maintaining oral health which is often ignored and } \\ \text { Keywords: } \\ \text { Covid-19; dental health } \\ \text { education; video games. }\end{array} \\ \text { through health education using the right media or tool to make it } \\ \text { moI: }\end{array}$

\section{INTRODUCTION}

The Corona Virus Disease-19 pandemic has an influence for all aspect especially the social life. The interaction between human is limited by distance that called social distancing. Social distancing is the important key to minimize the spread of SARS-CoV 2 inter human. Learning method for dental education should be innovated to keep on the learning process but away from being infected during pandemic.(Hu et al., 2020) School-aged children are groups that are prone to oral health problems, especially dental caries and periodontal disease.(Amelia Nurfalah, Emma Yuniarrahmah, 2014; Komara et al., 2019) In 2012, the World Health Organization (WHO) announced that dental caries is the most oral disease that happens among school-age children, reaches 60-90\%.(Alhayek et al., 
2018) The Center for Disease Control and Prevention (CDC) reported that dental caries is a dental problem with the highest prevalence among children.(Alhammad \& Salama, 2011) Based on Basic Health Research (RISKESDAS) in 2018, the prevalence of dental caries among children in Indonesia in the 5-9 years age group was $92.6 \%$ and in the $10-14$ years age group was $73.4 \%$. The prevalence of bleeding gums in the $5-9$ years age group was $9.6 \%$ and in the 10-14years age group was 14.3\%.(Riskesdas, 2018) This indicates that there are still many dental and oral problems among children and requires special attention from health workers.(Kantohe et al., 2016; Razi, P., \& Rosmawati, 2018)Oral health disease can interfere with a child's quality of life. Dental problems that are not treated will cause pain, which can interfere with the chewing function. This situation can affect the growth and development of children because it can interfere with eating habit and nutritional intake which results in other health problems. In addition, this condition can affect the function of speech, smile, and the psychosocial environment.(Alhayek et al., 2018; Kantohe et al., 2016) One of the causes of this disease is bad behaviour to maintain oral hygiene. This is based on the poor knowledge of oral health. Knowledge of the causes and ways of controlling them are needed to maintain children's dental health. Most of dental caries and periodontal disease are caused by plaque, so it is necessary to control plaque mechanically such as brushing teeth, cleaning interdental, cleaning the tongue and using toothpaste and also chemical cleanings such as the use of toothpaste and mouthwash. (Arianto et al., 2014; Halaris \& Wyche, 2019) Because of this poor knowledge, it is necessary to increase knowledge to change bad into good behaviour.

Knowledge is the result of "knowing" that is obtained after human sensing of an object or stimulus.(Notoatmodjo, 1997) Increasing the knowledge in school-age children can be done through oral health education. Dental and oral health education is carried out based on health needs with the aim of being able to change old behaviours into new ones that further improve children's health status.(Amelia Nurfalah, Emma Yuniarrahmah, 2014; Kantohe et al., 2016; Nazri Yanti et al., 2017) In the process of dental and oral health education, the use of appropriate educational tool is very important for children to increase their knowledge.(Amelia Nurfalah, Emma Yuniarrahmah, 2014; Nazri Yanti et al., 2017) Thus, the media is a tool to send the health messages.(Gejir et al., n.d.; Notoatmodjo, 2012) Broadly speaking, the media is divided into visual aids, audio aids, and audio-visual aids. Based on its function as health message delivery tool, educational media is divided into print media, electronic media and board media.(Gejir et al., n.d.; Notoatmodjo, 2012)Selecting of educational media that is effective and involves many senses will affect the success of understanding educational targets.(Kantohe et al., 2016; Nazri Yanti et al., 2017; Razi, P., \& Rosmawati, 2018) One of the educational media for children's dental and oral health is through video.(Olubunmi \& Olushola, 2013)

Video can be used for oral health education along with technological advances. This media can send health messages that are more interesting and easy to understand because they can be played over and over again through visualization of text, images, and sound so that they are more dynamic and effective.(Nazri Yanti et al., 2017; Supriyanto et al., 2019) Broadly speaking, this electronic media is included in the category of audio-visual aids because this media stimulates two senses at the same time, namely sight and hearing, so it is easy to deliver information to the brain and affects both short-term and long-term memory if supported by other factors such as attention, motivation, and prior knowledge.(Jumilah et al., 2013; Kantohe et al., 2016) However, to use this media requires a lot of money, this media also requires special skills in operating it and the user does not actively participate in 
interacting with the stimulus given and individuals must be able to remember the details of each short video playback process.(Hanif \& Prasko, 2018; Munir, 2017; Nazri Yanti et al., 2017; Razi, P., \& Rosmawati, 2018) One example of a video that educates dental and oral health is a video game.

Video as a medium for dental and oral health education has been widely used among children. Study in Nigeria has shown that videos that adapt to local culture and language can improve the oral hygiene of school-age children in low socio-economic groups. (Olubunmi \& Olushola, 2013) Kantohe in 2016 reported that video was effective in increasing knowledge of dental and oral health.(Kantohe et al., 2016) However, a study by Hermina in 2010 explained that video was not effective in educating children aged 6-7 years on how to brush their teeth.(Vera, 2010)

Therefore, a study was carried out to evaluate knowledge disparity of dental and oral health among students. Based on the description above, the media of dental health education is one of the important things to make children understand about dental health message. Knowledge disparity is one of the measurement to prove that media is an effective methode. This study aims to knowledge disparity of dental and oral health among students before and after education video game at SD Negeri 03 Pesanggrahan.

\section{METHOD}

The study is pre eksperiment study with one group pretest-posttest design. The participants are all fourth-grade students of SDN 03 Pesanggrahan, Jakarta Selatan $(\mathrm{N}=66)$. Children around 6 to 12 years old or school-aged children are still less aware of how to maintain oral hygiene. The efforts to maintain oral health should be done from an early age. Primary school age is an ideal time to give children dental health education. One of the efforts in improving oral health is modification of health education media. The research sample was a part of the population that was selected in a certain way and was considered as representative of the population by meeting the inclusion and exclusion criteria. The inclusion criteria were fourth-grade students of SDN 03 Pesanggrahan who have received approval from their parents to participate in this research and students who can operate their devices properly and have adequate internet access. Meanwhile, the exclusion criteria were students who had not watched the video completely and the students who step down from the research process.

The participant was taken by the total sampling method, where the entire population was the research sample because the population was less than 100 people.(Sari, 2016) Students were given a questionnaire pre-test through Google Forms to measure their dental and oral health knowledge before the intervention, then the dental and oral health education was done by educating them about characteristics of healthy and unhealthy teeth, types of teeth, frequency of brushing including proper brushing movements which were presented in a video game that was connected to Google Drive and distributed through WhatsApp group chat. The last step was doing post-test by distributing electronic questionnaires through Google Forms to the students after giving the oral health education. All procedures for the pre-test, post-test, and watching educational videos were directly supervised by the parents of the students. Data analysis used was Kolmogorov Smirnov test as a normality test and the Wilcoxon test as a test for differences in student's knowledge before and after giving education through a video game.

This research has limited conditions that cannot be controlled due to the distance education process and it needs good cooperation between researchers, teachers, and parents. There were also technical obstacles such as internet data and electronic devices so that electronic questionnaire collection could not be done simultaneously. We suggest to use media 
that stimulates many senses for further research and it is necessary to conduct further research by comparing oral health education with other types of media so that it can be seen which types of media are best for dental and oral health education activities.

\section{RESULT AND DISCUSSION}

The participant consisted of $45 \%$ male and $55 \%$ female, nine percent is 9 -year-old. 10 -year-old by $67 \%$ and 11 -year-old by $24 \%$.

Table 1. Average knowledge value of pre-test and post-test health education with a video game $(\mathrm{N}=66)$

\begin{tabular}{ccc}
\hline & Mean & Standard Deviation \\
\hline Pre-test & 39.52 & 3.014 \\
Post-test & 40.68 & 3.324 \\
\hline
\end{tabular}

Source: analyzed by author, 2021.

Table 1 shows the average value before intervention is 39.52 and after intervention is 40.68 .

Table 2. Dental health education through a video game $(\mathrm{N}=66)$

\begin{tabular}{|c|c|c|c|}
\hline & Increase & Decrease & Constant \\
\hline Knowledge & 37 (56\%) & $15(22,73 \%)$ & $14(21,21 \%)$ \\
\hline
\end{tabular}

Table 2 shows 37 children have been increasing their knowledge score, 15 children have been decreasing their knowledge score and 14 children did not experience a change in their knowledge score.

Table 3. The result of the pre-test and post-test knowledge test for health education through a video game $(\mathrm{N}=66)$

\begin{tabular}{lll}
\hline & Median (minimum-maximum) & p value \\
\hline Pre-test & $39(33-45)$ & \\
Post-test & $40(33-45)$ & $0,001^{*}$ \\
\hline
\end{tabular}

${ }^{*} \mathrm{p} \leq 0.05$, CI 95\%, Wilcoxon test

Source: analyzed by author, 2021.

Table 3 shows there is a significant difference between before and after education through a video game where $\mathrm{p}$ $<0.05$.

\section{Discussion}

On March, 2020, Persatuan Dokter Gigi Indonesia (PDGI) recommended that dental practices postpone elective dental procedures until the pandemic is done, and provide emergency-only dental services to help keep patients from burdening hospital emergency departments. The COVID-19 pandemic presents an opportunity for the dental profession to shift from an approach focused on curative intervention to prevention. One of the most effective steps to prevent oral disease is doing oral health promotion. Oral health promotion during this pandemic has several obstacles, including the lack of direct contact to the target due to social distancing regulations, the delivery of oral health education materials must be done over a long distance. In children's groups, it is also necessary to use interesting educational teaching aids, one of which is by using video games. This study explains the differences in oral dental health knowledge before and after education using an innovative dental and oral health education tool, video games. 
The knowledge about dental and oral health based on data analysis obtained a high average of knowledge before the education through a video game was given (Table 1), this data explains that before receiving education about dental and oral health, at least they already know the things that cause dental and oral health disease. In SD Negeri 03 Pesanggrahan is an elementary school that the dental health education is given with manual method through Usaha Kesehatan Gigi Sekolah program. This is in line with a study by Wulandari in 2018 which stated that support from teachers and schools resulting in the behaviour of maintaining good oral health as well, in other words, it is based on adequate knowledge.(Sari et al., 2019) This is also strengthened by Ikenasya in 2017 reported that schools with UKGS together with good knowledge of the teachers in line with the low dental caries status category for students.(Farahiyah Ikenasya \& Novita, 2017)

The increase in knowledge value based on the results of data analysis showed that most children have been increasing their knowledge value (Table 2). This is due to several factors such as the use of this tool in the educational process, education through electronic media, the use of audiovisual aids in the educational process and the animated elements found in the video game. The delivery of health messages through the media is proven increasing knowledge of students, this is by the essence of the educational media itself, as an intermediary in sending health messages to educational target, because of this intermediary, the information can reach the educational target.(Gejir et al., n.d.; Notoatmodjo, 2012) Also, this is in line with a study by Jumilah in 2015 where there was no difference between the pre-test and posttest knowledge in the group that did not use the media.(Jumilah et al., 2013) Apart from the use of media to distribute health messages, the increased value of knowledge is also influenced by the electronic media factor as an educational media in this study.
Delivering health messages through video games as electronic media is proven to increase children's knowledge. This is consistent with the classification of the media as of channelling health messages along with print and board media.(Gejir et al., n.d.; Notoatmodjo, 2012) In several studies such as a study by Kantohe in 2016 which stated that electronic media is more effective in increasing knowledge of dental and oral health compared to print media (flipchart).(Kantohe et al., 2016) However, it is not in line with a study by Majid in 2020 which stated there was no difference in knowledge between the health education group with printed media (educational comics) and electronic media (animated videos).(Majid et al., 2020) The increased value of student knowledge can also be influenced by video as a audio-visual aids which is superior to a visual aids and audio aids. This hearing aids is proven to be superior because it can stimulate more than one of the five senses, namely the sense of sight and the sense of hearing.(Majid et al., 2020) This is in line with a study by Sitanaya in 2019 which reported that audio-visual aids are more effective than visual media (flipchart) in increasing students' knowledge about dental caries.(Sitanaya, 2019)Besides, this is in line with a study by Papilaya in 2016 which stated that audiovisual aids are better than audio aids in improving the behaviour to maintain children's oral and dental health, in other words, the increased behaviour is based on better knowledge.(Papilaya et al., 2016) According to Maulana quoted by Kuswareni, eyes are one of the five senses that have major influence in delivering knowledge to the brain (approximately 75-87\%) then the other $13-25 \%$ are conveyed by the other five senses.(Kuswareni et al., 2016) In this educational aid, video stimulates the visual sense by $75 \%$ and the sense of hearing by 13\%.(Majid et al., 2020) This is also under the principles of making educational aids, knowledge is accepted by the five senses so that the more senses are stimulated the more knowledge that can be absorbed by 
children.(Kantohe et al., 2016) Because it stimulates several senses, it affects both short and long-term memory in children.(Majid et al., 2020)

In table 2 there are also children who experience a decrease in the value of knowledge. This is due to the child's attention that cannot be maintained because there is no interaction in the form of playing games actively. Children tend to feel depressed because they did not do a physical activity in return for something that stimulates them, even though at that age children tend to be active in physical activity. This is in line with research conducted by Baboo in 2017 where children who play video games can increase the value of social behaviour, but if only watching video games, it reduces the value of social behaviour in other words, it is based on insufficient knowledge.(Baboo, 2017)

In Table 3, it is shown that there is a significant difference between the value of knowledge before and after being given health education through a video game. This difference in knowledge is caused by the animation and game elements in the video. In a video game, it is inseparable from the animated elements shown during video playback. Moving images that are presented in various colours and inserted with oral health material are able to attract children's attention so that they can increase students' learning motivation.(Majid et al., 2020) Animations that attract attention make respondents remember and material so as to increase memory.(Papilaya et al., 2016) This is in line with a study by Sari, 2017 which states that videos that contain animation are more effective than videos that do not contain animation. This is also reinforced by a study by Alhayek et al. in 2018 in Riyadh which stated that animated video media and demonstrations were effective for conveying messages on dental health, but animated videos had the advantage of using a short time in delivering dental health information.(Alhayek et al., 2018) In addition to animation elements, there are also elements of Android games in the video.
Games are something that children love, games that adapt to the development of this technology can attract children's attention to first impressions. This adjusts to the characteristics of elementary school children in general, that children still enjoy playing. This is in line with a study by Santoso in 2019 which stated that the Android-based monopoly game media was feasible and effective as a dental health education media.(Alhayek et al., 2018)

\section{CONCLUSION}

From the study, it can be concluded that using video games as an innovation tool for dental health education can be used as an alternative to promote the oral health of children during the Covid-19 pandemic. There is knowledge disparity of dental and oral health among students before and after education video game at SDN 03 Pesanggrahan, Jakarta Selatan. The process of dental health education using video game is an effective way to increase students'knowledge about dental health. Animations on video game that attract attention make children can increase the memory. Providing children with oral health education through a interesting method, such as video games, might provide them with a positive media influence. In addition, parents are indeed going to be part of the intervention in this study, as they will be required to guide the child through the game. Moreover, parents might learn indirectly, as some evidence suggests that children can transmit knowledge to their parents. We suggest, oral health care providers must clearly communicate the importance of oral health and promote the oral disease prevention by using an innovation tools such as video game for children during the pandemic. Video games with other more interesting dental health education materials can be developed in next study. 


\section{Acknowledgement}

We thank for all of the students, teachers, and parents at SDN 03 Pesanggrahan, Jakarta Selatan.

\section{REFERENCE}

Alhammad, N. S., \& Salama, F. S. (2011). Effectiveness of an infant oral health care educational intervention on knowledge of dental students. Advances in Medical Education and Practice, 2(August), 193-199. https://doi.org/10.2147/AMEP.S1 9415

Alhayek, A. I. A., Alsulaiman, M. J., Almuhanna, H. A., Alsalem, M. A., Althaqib, M. A., Alyousef, A. A., Alabdali, J. N., Alqahtani, S. A., \& Ansari, S. H. (2018). The effect of conventional oral health education versus animation on the perception of Saudi males in primary school children. Journal of International Oral Health, 10(3), 121-126. https://doi.org/10.4103/jioh.jioh_ 86_18

Amelia Nurfalah, Emma Yuniarrahmah, D. A. P. (2014). Efektivitas Metode Peragaan Dan Metode Video Terhadap Pengetahuan Penyikatan Gigi Pada Anak Usia 9-12 Tahun Di Sdn Keraton 7 Martapura. Jurnal Kedokteran Gigi, II(2), 40.

Arianto, Shaluhiyah, Z., \& Nugraha, P. (2014). Perilaku Menggosok Gigi Pada Sisiwa Sekolah Dasar Kelas V Dan Vi Di Kecamatan Sumberjo. 127-135.

Baboo, S. (2017). Differential Effects on Playing and Watching Videogames on the Problem Solving and Pro Social Behaviour of Middle School Students. International Journal of Education and Psychological Research, 6(3), 1-4.
Farahiyah Ikenasya, D., \& Novita, F. (2017). Murid Sekolah Dasar dengan UKGS dan Tanpa UKGS (Studi pada SDN 16 dan SDN 49 Banda Aceh). Caninus Denstistry, 2(3), 131-136.

Gejir, I. N., Agung, A. A. G., Ratih, I. A. D. K., Mustika, I. W., Suanda, I. W., Widiari, N. N., \& Wirata, I. N. (n.d.). Media Komunikasi dalam Penyuluhan Kesehatan. Penerbit Andi.

Halaris, J. F., \& Wyche, C. J. (2019). Active Learning Workbook for Wilkins' Clinical Practice of the Dental Hygienist. Jones $\backslash \&$ Bartlett Learning.

Hanif, F., \& Prasko, P. (2018). the Difference of Counseling With Video Media and Hand Puppets To Improving Knowledge of Dental and Oral Health in Elementary School Students. Jurnal Kesehatan Gigi, $\quad 5(2), \quad 1$. https://doi.org/10.31983/jkg.v5i2 .3854

Hu, J., Zou, H., Dai, Y., \& Feng, Z. (2020). How to keep students engaged in oral health education during the COVID-19 pandemic. Journal of Dental Education, August, 2-4. https://doi.org/10.1002/jdd.1242 0

Jumilah, J., Jauhari, A. H., \& Ridha, A. (2013). Efektifitas Media Poster terhadap Peningkatan Pengetahuan tentang Kesehatan Gigi. Jurnal Mahasiswa Dan Peneliti Kesehatan - JuMantik, 1-12.

Kantohe, Z. R., Wowor, V. N. S., \& Gunawan, P. N. (2016). Perbandingan efektivitas pendidikan kesehatan gigi menggunakan media video dan flip chart terhadap peningkatan pengetahuan kesehatan gigi dan 
mulut anak. E-GIGI, 4(2), 7-12. https://doi.org/10.35790/eg.4.2.2 016.13490

Komara, Z. Z., Pramuditha, R., Widartika, \& Moviana, Y. (2019). Pendidikan Gizi Seimbang Dengan Media Video Lagu Terhadap Pengetahuan Dan Perilaku Siswa Sekolah Dasar. Jurnal Riset Kesehatan, 11(2), 6066.

Kuswareni, N., Adhani, R., \& ARifin, S. (2016). Efektivitas Penyuluhan Metode Irene's Donut, Konvensional dan Video Terhadap Perubahan Indeks Plak Pada Anak. Dentino Jurnal Kedokteran Gigi, 1(1), 184-206.

Majid, Y. A., Carera, A. M., \& Trilia, T. (2020). Media Komik Edukasi Dan Video Animasi Sebagai Media Promosi Kesehatan Tentang Karies Gigi Pada Anak Sekolah Dasar. Jurnal 'Aisyiyah Medika, 5(1), 1320.

https://doi.org/10.36729/jam.v5i 1.306

Munir. (2017). Pembelajaran Digital. Penerbit Alfabeta.

Nazri Yanti, G., Mayasari Alamsyah, R., Ella Natassa, S., \& Nazri Yanti Departemen Ilmu Kedokteran Gigi Pencegahan, G. (2017). Effectiveness of Dental Health Education Using Cartoons Video Showing Method on Knowledge and Oral Hygiene of Deaf Children in Yayasan Karya Murni Medan. International Journal of Applied Dental Sciences, 3(2), 86-90.

Notoatmodjo, S. (1997). Ilmu Kesehatan Masyarakat; Prinsip-prinsip Dasar. PT Rineka CIpta.

Notoatmodjo, S. (2012). Promosi Kesehatan dan Perilaku Kesehatan. PT Rineka CIpta.
Olubunmi, B., \& Olushola, I. (2013). Effects of information dissemination using video of indigenous language on 11-12 years children's dental health. Ethiopian Journal of Health Sciences, 23(3), 201-208. https://doi.org/10.4314/ejhs.v23i 3.2

Papilaya, E. A., Zuliari, K., \& . J. (2016). Perbandingan pengaruh promosi kesehatan menggunakan media audio dengan media audio-visual terhadap perilaku kesehatan gigi dan mulut siswa SD. E-GIGI, 4(2), 15.

https://doi.org/10.35790/eg.4.2.2 016.14261

Razi, P., \& Rosmawati, R. (2018). Perbandingan Efektivitas Edukasi Kesehatan Gigi Dengan Metode Bermain , Video Dan Boneka Dalam Meningkatkan Keterampilan. Jurnal Bahana Kesehatan Masyarakat, 2(2), 101.

Riskesdas. (2018). Hasil Utama Riset Kesehatan Dasar. Kementrian Kesehatan Republik Indonesia, 1100. https://doi.org/1 Desember 2013

Sari, R. P. (2016). HUBUNGAN PENGETAHUAN GURU TENTANG MANAJEMEN PEMBELAJARAN DENGAN KINERJA GURU DI MTS NEGERI 2 ABSTRAK Penelitian ini bertujuan untuk mengetahui : (1) Untuk mengetahui bagaimana tingkat pengetahuan guru tentang manajemen pembelajaran di MTs Negeri 2 Medan. 02, 105-115.

Sari, R. P., Elianora, D., \& Bakar, A. (2019). Perbandingan Efektivitas Penyuluhan Dengan Video Dan Animasi Tentang Makanan Kariogenik Terhadap Pengetahuan Siswa Kelas Iv Di Sdn 027Sungai 
Sapih Kec. Kuranji, Padang. B-Dent, Jurnal Kedokteran Gigi Universitas Baiturrahmah, 4(2), 117-125. https://doi.org/10.33854/jbdjbd. 103

Sitanaya, R. I. (2019). Efektivitas Flip Chart Dan Media Audiovisual Terhadap Peningkatan Pengetahuan Siswa SD Negeri Katangka tentang Karies gigi. Jurnal Ilmiah Kesehatan Sandi Husada, 10(2), 63-68. https://doi.org/10.35816/jiskh.v1 $0 \mathrm{i} 2.110$

Supriyanto, I., Yubiliyana, G., \& Desy Arya, I. F. (2019). Dental Health Education Promotion using Video Blogs (Vlog) and Treatment Methods on Teething Practices in Basic School Children in Bandung City. Jurnal Kesehatan Gigi, 6(2), 136-140.

https://doi.org/10.31983/jkg.v6i2 .5491

Vera, H. (2010). Efektivitas Metode Pengajaran Cara Menyikat Gigi Terhadap Penurunan Indeks Plak Anak Usia 3-5 Tahun. Dentika Dental Journal, 15(1), 42-45. 